Volume 1, Nomor 2, Oktober 2020, 54-66

JTTM: Jurnal Terapan Teknik Mesin

p ISSN 2721-5377| e ISSN 2721-7825

\title{
ALAT PENGERING SALE PISANG DENGAN ENERGI SURYA
}

\section{BANANA SALE DRYER WITH SOLAR ENERGY}

\author{
Bina Age Aratama ${ }^{1}$, Awang Surya ${ }^{2 *}$ \\ 1,2* Program Studi Teknik Mesin, Sekolah Tinggi Teknologi Muhammadiyah Cileungsi \\ 1,2 Jl. Anggrek, No 25, Perum PT.SC, Cileungsi, Bogor, Jawa Barat, Indonesia 16820 \\ *Koresponden Email: awang_surya@yahoo.com
}

\begin{abstract}
Abstrak. Tanaman pisang adalah salah satu tanaman unggulan di Indonesia, karena besarnya volume produksi nasional yang melebihi komoditi lainnya. Produksi pisang di Indonesia yang cukup tinggi tidak sebanding dengan tingkat konsumsi masyarakat, sehingga mengakibatkan banyaknya pisang yang tidak dimanfaatkan karena daya simpan buah pisang yang relatif singkat. Salah satu solusi dari masalah ini adalah dengan membuat pisang menjadi produk olahan yaitu salai pisang. Salai pisang dibuat dari pisang matang dengan cara pengasapan atau pengeringan matahari. Proses pengasapan mengakibatkan pencemaran lingkungan dan tidak baik bagi kesehatan jika terhirup terus menerus. Proses pengeringan pisang di bawah terik matahari membutuhkan waktu cukup lama, tiga sampai enam hari. Penelitian yang telah dilakukan ini menghasilkan prototipe alat pengering salai pisang dengan sumber energi matahari. Alat ini punya kemampuan mengeringkan buah pisang sampai kadar air menjadi di bawah 40\%. Waktu yang dibutuhkan rata-rata 212 menit atau 3 jam 32 menit. Kapasitas penguapan kadar air dari alat yang dibuat adalah sebesar $0.0114 \mathrm{~kg} / \mathrm{jam}$. Efisiensi termal dari alat yang dibuat adalah sebesar $15.70 \%$.
\end{abstract}

Kata Kunci: Salai pisang, Alat pengering, Energi Surya.

\begin{abstract}
Banana plants are one of the leading plants in Indonesia, due to the large volume of national production that exceeds other commodities. Banana production in Indonesia, which is quite high, is not proportional to the level of public consumption, resulting in the number of bananas that are not used because of the relatively short shelf life of bananas. One solution to this problem is to make bananas into processed products, namely banana slices. Banana slices are made from ripe bananas by smoking or drying the sun. The smoking process causes environmental pollution and is not good for health if inhaled continuously. The process of drying bananas in the sun takes a long time, three to six days. This research has produced a prototype of a banana leaf dryer with solar energy sources. This tool has the ability to dry bananas until the water content becomes below 40\%. The average time needed is 212 minutes or 3 hours 32 minutes. The evaporation capacity of the water content of the device made is $0.0114 \mathrm{~kg} / \mathrm{hour}$. The thermal efficiency of the equipment made is $15.70 \%$.
\end{abstract}

Keywords: Banana slices, Dryers, Solar Energy.

\section{PENDAhuluan}

Tanaman pisang adalah salah satu tanaman unggulan di Indonesia, karena besarnya volume produksi nasional yang melebihi komoditi lainnya. Data produksi buah Indonesia tahun 2013, menunjukkan bahwa produksi pisang adalah sebesar 5.359.126 ton. Ini merupakan jumlah produksi buah terbesar dibandingkan dengan buah lainnya. Dari data tersebut memperlihatkan bahwa tanaman pisang merupakan salah satu tanaman yang melimpah di Indonesia [1].

Permintaan pisang untuk industri pengolahan skala rumah tangga $(10-50 \mathrm{~kg} / \mathrm{hari})$, skala UKM kripik (100-120 kg/hari), salai (1.5-2 ton/bln), ledre (70-120 kg/hari), puree (300-500 kg/h) dan tepung 
(700-1000 kg/minggu). Skala besar, membutuhkan kapasitas $+10-12$ ton pisang segar/hari [2].

Produksi pisang di Indonesia yang cukup tinggi tidak sebanding dengan tingkat konsumsi masyarakat, sehingga mengakibatkan banyaknya pisang yang tidak dimanfaatkan karena daya simpan buah pisang yang relatif singkat. Salah satu solusi dari masalah ini adalah dengan membuat pisang menjadi produk olahan yaitu salai pisang [3].

Industri sale pisang salah satu industri rumah tangga [4]. Usaha sale pisang goreng menghasilkan keuntungan yang lebih tinggi dibanding usaha keripik pisang goreng [5] [6]. Dari hasil penelitian tersebut menunjukkan bahwa usaha sale pisang goreng memiliki prospek yang sangat baik [6]

Salai pisang dibuat dari pisang matang dengan cara pengasapan atau pengeringan matahari. Proses pengasapan mengakibatkan pencemaran lingkungan dan tidak baik bagi kesehatan jika terhirup terus menerus. Proses pengeringan pisang di bawah terik matahari membutuhkan waktu cukup lama, tiga sampai enam hari.

Untuk perlu dirancang alat yang bisa mempercepat proses pengeringan sehingga kapasitas produksi meningkat.

\section{METODE}

Urutan langkah pada penelitian ini secara ringkas terlihat pada diagram alir (flowchart) pada gambar 1. Kegiatan utama dari penelitian yaitu: perancangan, pembuatan dan uji pengeringan buah pisang. Proses perancangan dan pembuatan alat dilaksanakan dari 26 November yang bertempat di workshop Naga Jaya di Kp. Tarikolot RT 06 RW 01 Gg. Sabur no. 4 Kec. Citeureup Kab. Bogor. Sedangkan uji pengeringan buah pisang dilakukan di halaman rumah Bapak Kamdani, Kp. Pabuaran RT 07/RW 09 Kec. Cibinong Kab. Bogor, Tanggal 9 Mei 2019 pada siang hari dengan cuaca yang cerah.

Untuk menguji kelayakan alat mengacu pada standar yang telah ditetapkan oleh Badan Standardisasi Nasional (BSN). 


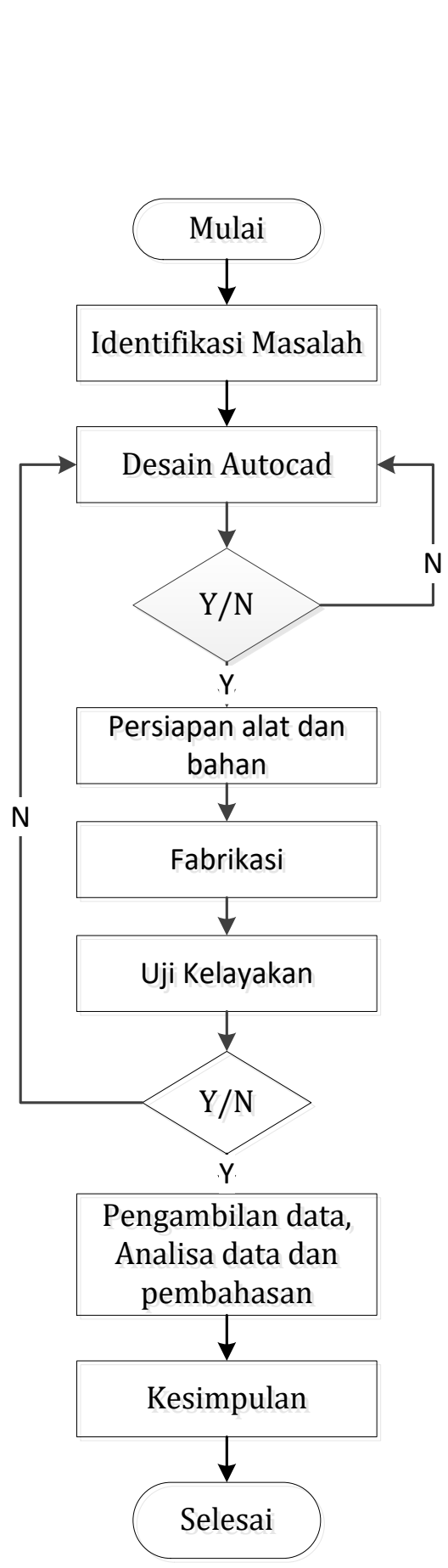

Gambar 1. Flowchart metode penelitian

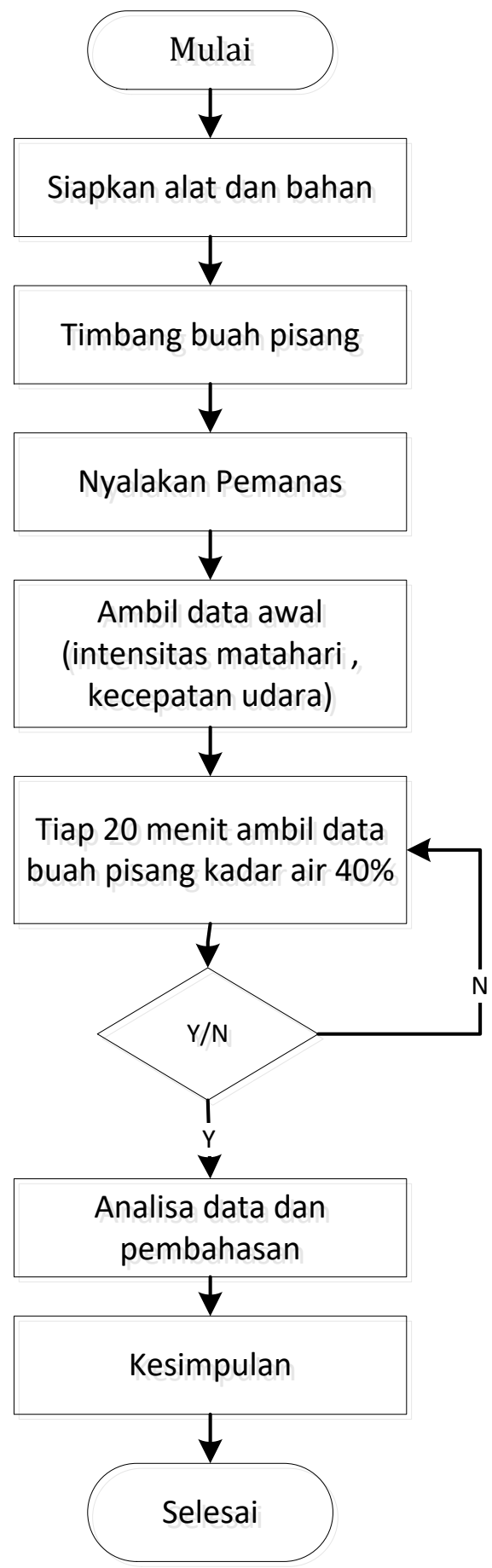

Gambar 2. Flowchart langkah pengujian alat pengering

Dalam pembuatan salai pisang berdasarkan SNI 01-4319-1996 maksimal memiliki kadar air $40 \%$ seperti yang ditunjukan pada tabel 1. Untuk mengetahui prestasi dari alat yang telah dirancang maka perlu adanya pengujian sistem pengering. Proses pengeringan dilakukan dengan meletakkan buah pisang pada tray dalam ruang pengering. Buah pisang dikupas dipisahkan dengan kulitnya kemudian 
dikerok pada bagian yang berwarna putihnya dan dipotong-potong kemudian diletakan pada tray pengering.

Tabel 1. Standar mutu salai pisang berdasarkan SNI 01-4319-1996

\begin{tabular}{|c|c|c|c|}
\hline No & Kriteria uji & Satuan & Persyaratan \\
\hline 1 & Keadaan & & \\
\hline 1.1 & Bau & - & Normal \\
\hline 1.2 & Rasa & - & Manis,khas \\
\hline 1.3 & Warna & - & Normal, khas \\
\hline 1.4 & Air & $\% \mathrm{~b} / \mathrm{b}$ & Maksimal 40 \\
\hline 1.5 & $\mathrm{Abu}$ & $\% \mathrm{~b} / \mathrm{b}$ & Maksimal 2 \\
\hline 1.6 & Gula sebagai sukrosa & $\% \mathrm{~b} / \mathrm{b}$ & Minimal 35 \\
\hline 1.7 & Zat pengawet ( $\mathrm{SO} 2$ ) & $\mathrm{Mg} / \mathrm{kg}$ & Maksimal 500 \\
\hline 2 & Cemaran logam & & \\
\hline 2.1 & Timbal $(\mathrm{Pb})$ & $\mathrm{Mg} / \mathrm{kg}$ & Maksimal 500 \\
\hline 2.2 & Tembaga (cu) & $\mathrm{Mg} / \mathrm{kg}$ & Maksimal 10 \\
\hline 2.3 & Seng (zn) & $\mathrm{Mg} / \mathrm{kg}$ & Maksimal 40 \\
\hline 2.4 & Raksa (Hg) & $\mathrm{Mg} / \mathrm{kg}$ & Maksimal 0.05 \\
\hline 2.5 & Arsen (As) & $\mathrm{Mg} / \mathrm{kg}$ & Maksimal 1 \\
\hline 3 & Cemaran mikroba & & \\
\hline 3.1 & E. coli & $\mathrm{APM} / \mathrm{g}$ & Negatif \\
\hline 3.2 & Angka lempeng total & Koloni/g & Maksimal 1 x 106 \\
\hline 3.3 & Kapang dan khamir & Koloni /g & Maksimal 1 x 104 \\
\hline
\end{tabular}

Langkah-langkah pengambilan data pengujian alat pengering yang telah dirancang, maka mengikuti flowchart pada gambar 2.

Proses pengambilan data mula-mula buah pisang diambil dua potongan yaitu potongan pisang yang berada pada tray 1 dan 2 kemudian timbang massanya. Pengukuran massa dengan cara menimbang buah pisang setiap 20 menit sekali. Data dari sampel yang diambil kemudian dihitung kadar air buah pisang tiap tray. 
Pengujian ini dilakukan sebanyak 5 kali untuk memastikan kebenaran dalam kelayakan alat dalam proses pengeringan.

Pada proses ini diperoleh data-data dari hasil pengujian pada sistem pengeringan menggunakan tenaga surya untuk pengeringan buah pisang. Kemudian data-data dari hasil pengujian tersebut dicatat. Selanjutnya dianalisis untuk mengetahui prestasi sistem pengeringan hasil penyusutan kadar air dari buah pisang terhadap waktu yang diperlukan. Adapun variabel-variabel yang diukur pada pengujian ini.

1. Intensitas matahari (It) dan waktu pengeringan

2. Kecepatan udara masuk

3. Temperatur udara luar (T1)

4. Temperatur udara masuk (T2)

5. Temperatur pemanas elektrik (T3)

6. Temperatur udara masuk ruang pengering (T4)

Massa sampel awal dan massa akhir buah pisang hingga mencapai kadar air $40 \%$

\section{HASIL DAN PEMBAHASAN}

Alat yang dirancang menggunakan sumber dari sinar matahari dan pemanas elektrik yang sumber arusnya didapat dari panel surya.

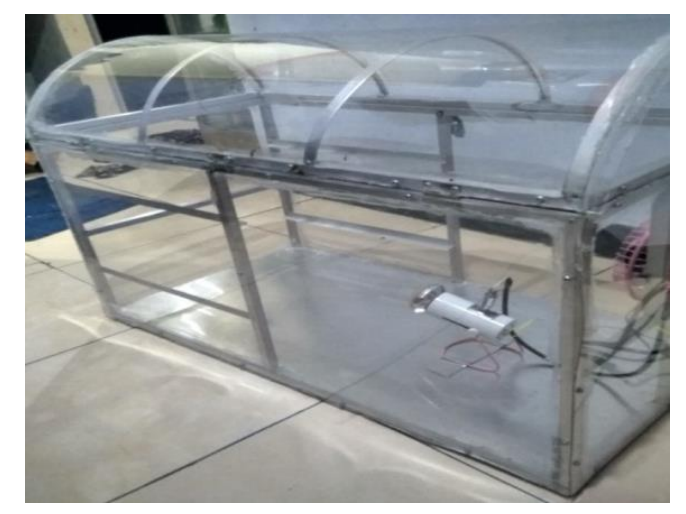

Gambar 3. Alat pengering

Pemanas berfungsi menaikkan suhu yang ada di dalam ruangan pengering. Selanjutnya terjadi penguapan air yang ada dalam buah pisang. Pemanas yang digunakan dalam alat pengering berupa lampu spot pemanas, dengan posisi menghadap ke tray. Lampu ini berdaya 60 watt. Tray berfungsi meletakan pisang yang akan dikeringkan. Ukuran tray 38 × $38 \mathrm{~cm}$, dengan bahan kawat stainless steel.

Sel surya merupakan sebuah perangkat yang mengubah energi sinar matahari menjadi energi listrik dengan proses efek fotovoltaic.[7] Panel surya yang digunakan memiliki spesifikasi $50 \mathrm{WP}$ berbentuk persegi panjang dengan ukuran 53 x $67 \mathrm{~cm}$. Energi listrik yang disalurkan ke kipas dan pemanas. Panas yang dihasilkan berpindah secara konveksi untuk mengeringkan buah pisang. 
Penutup alat pengering terbuat dari polikarbonat bening yang berguna untuk menyerap sinar matahari yang masuk ruang pengering. Polikarbonat suatu kelompok polimer termoplastik, mudah dibentuk dengan menggunakan panas. Plastik jenis ini digunakan secara luas dalam industri kimia saat ini. Plastik ini memiliki banyak keunggulan, yaitu ketahanan termal dibandingkan dengan plastik jenis lain, tahan terhadap benturan, dan sangat bening.[8]

Radiasi panas matahari masuk ke dalam ruang pengering dipantulkan dan diserap oleh plat aluminium. Hal ini menyebabkan perpindahan panas pada buah pisang sehingga terjadi penguapan [9]. Akibat dari penguapan ini terjadi perbedaan tekanan dalam ruang pengering dengan tekan luar sehingga uap air mengalir melalui lubang ventilasi yang dijelaskan pada gambar 4 .

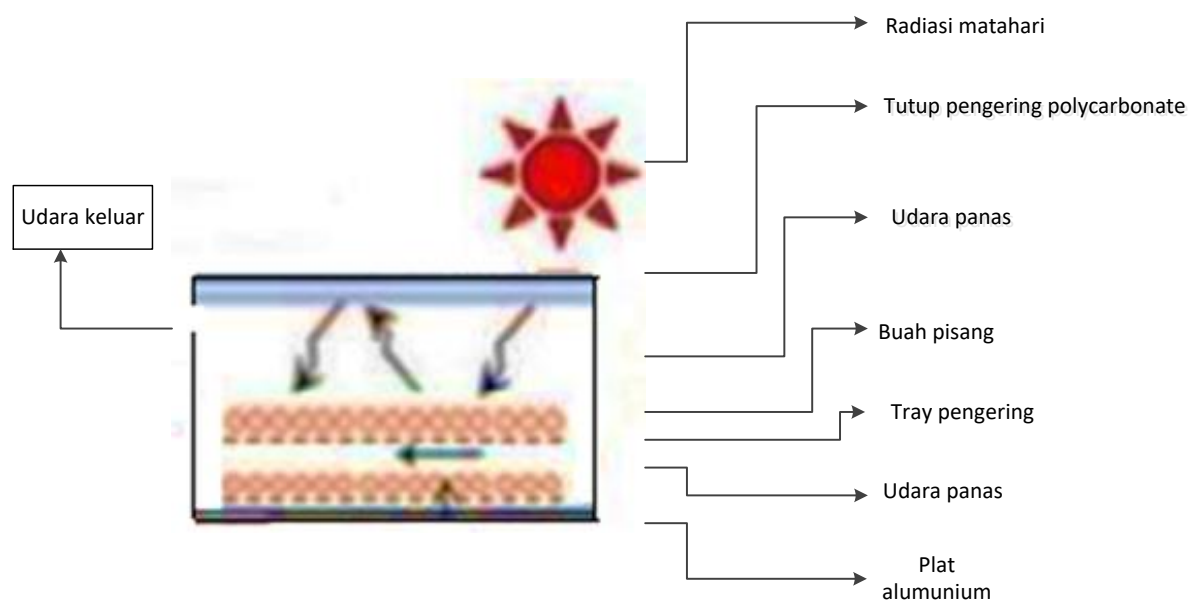

Gambar 4. Sistem kerja alat pengering tenaga surya

Dari 5 kali pengujian pengeringan buah pisang dengan menggunakan alat yang sudah dibuat. Pada saat pengujian buah pisang yang dikeringkan diambil satu potongan dari tiap tray sebagai sampel. Waktu pengujian pengeringan dimulai 9:00 hingga selesai mencapai kadar air maksimal $40 \%$ sesuai SNI 01-4319-1996 Standar Mutu Salai Pisang [10]. Kemudian setiap 20 menit dilakukan pengukuran. Untuk mengetahui pengurangan kadar air awal dalam buah pisang dilakukan pengujian pada laboratorium PT. SARASWATI INDO GENETECH. Kadar air awal buah pisang saat pengujian di laboratorium sebesar $72.63 \%$.

Pengujian kadar air ini mengacu pada SNI 01-2891-1992 tentang cara menguji makanan dan minuman. Pengujian kadar air membandingkan berat awal sebelum pengeringan dengan sesudah pengeringan dalam bentuk prosentase.

Kadar air $=\frac{W}{W 1} \times 100 \%$

Dimana: $\quad \mathrm{W}=$ bobot cuplikan sebelum dikeringkan dalam satuan gram

$\mathrm{W} 1=$ kehilangan bobot setelah dikeringkan dalam satuan gram 
Alat Pengering Sale Pisang Dengan Energi Surya

Berdasarkan pengujian yang telah dilakukan maka didapatkan hasil pada tabel 1, mulai dari pukul 09.00-12.40, menunjukkan penyusutan yang stabil. Namun hasil ini belum maksimal yang didapat untuk mendapatkan nilai yang sesuai dengan kebutuhan. Pengujian ini dilakukan mulai tgl 11 Maret 2019, 17 Agustus 2019, 18 Agustus 2019, 19 Agustus 2019, 20 Agustus 2019, untuk mengetahui hasil pengeringan salai pisang, sesuai dengan tabel 2,3,4,5,6.

Tabel 2. Pengujian 1 penurunan kadar air tiap 20 menit (11 Maret 2019).

\begin{tabular}{cccccc}
\hline Waktu & Menit & \multicolumn{2}{c}{$\begin{array}{c}\text { Massa Sampel Bahan } \\
\text { Tray (gram) }\end{array}$} & \multicolumn{2}{c}{ Kadar Air Sampel bahan } \\
\multicolumn{7}{c}{ Tray } \\
\hline 9.00 & 0 & 13.00 & 11.00 \\
9.20 & 20 & 13.00 & 11.00 & $72.63 \%$ & $72.63 \%$ \\
9.40 & 40 & 12.00 & 9.90 & $67.04 \%$ & $65.37 \%$ \\
10.00 & 60 & 11.30 & 8.60 & $63.13 \%$ & $56.78 \%$ \\
10.20 & 80 & 10.90 & 7.80 & $60.90 \%$ & $51.50 \%$ \\
10.40 & 100 & 9.87 & 6.92 & $55.14 \%$ & $45.69 \%$ \\
11.00 & 120 & 8.96 & 6.80 & $50.06 \%$ & $44.90 \%$ \\
11.20 & 140 & 8.52 & 6.56 & $47.06 \%$ & $43.31 \%$ \\
11.40 & 160 & 8.04 & 6.31 & $44.92 \%$ & $41.66 \%$ \\
12.00 & 180 & 7.62 & 6.02 & $42.57 \%$ & $39.75 \%$ \\
12.20 & 200 & 7.20 & 5.79 & $40.23 \%$ & $38.32 \%$ \\
12.40 & 220 & 6.70 & 5.50 & $37.43 \%$ & $36.23 \%$ \\
\hline
\end{tabular}

Tabel 3. Pengujian 2 penurunan kadar air tiap 20 menit (17 Agustus 2019).

\begin{tabular}{cccccc}
\hline Waktu & Menit & \multicolumn{2}{c}{$\begin{array}{c}\text { Massa Sampel Bahan } \\
\text { Tray (gram }\end{array}$} & \multicolumn{2}{c}{ Kadar Air Sampel bahan } \\
\multicolumn{5}{c}{ Tray } \\
\hline 9.00 & 0 & 6.17 & 7.50 \\
9.20 & 20 & 6.17 & 7.50 & $73.63 \%$ & $72.63 \%$ \\
9.40 & 40 & 5.90 & 7.33 & $69.45 \%$ & $70.98 \%$ \\
10.00 & 60 & 5.13 & 6.74 & $60.39 \%$ & $65.27 \%$ \\
10.20 & 80 & 4.93 & 6.30 & $58.03 \%$ & $61.01 \%$ \\
10.40 & 100 & 4.25 & 5.88 & $50.03 \%$ & $56.94 \%$ \\
11.00 & 120 & 3.73 & 5.35 & $43.91 \%$ & $51.81 \%$ \\
11.20 & 140 & 3.60 & 5.10 & $42.38 \%$ & $49.39 \%$ \\
11.40 & 160 & 3.37 & 4.76 & $39.67 \%$ & $46.10 \%$ \\
12.00 & 180 & 3.25 & 4.50 & $38.26 \%$ & $43.58 \%$ \\
12.20 & 200 & 3.05 & 4.05 & $35.90 \%$ & $39.22 \%$ \\
\hline
\end{tabular}


Pengujian pada tabel 4 menunjukan penurunan yang stabil dari sampel sebelumnya dengan cara yang sama.

Tabel 4. Pengujian 3 penurunan kadar air tiap 20 menit (18 Agustus 2019).

\begin{tabular}{cccccc}
\hline Waktu & Menit & \multicolumn{2}{c}{$\begin{array}{c}\text { Massa Sampel Bahan } \\
\text { Tray (gram }\end{array}$} & $\begin{array}{c}\text { Kadar Air Sampel bahan } \\
\text { Tray }\end{array}$ \\
\hline 9.00 & 0 & 7.27 & 6.92 & & \\
9.20 & 20 & 7.27 & 6.92 & $72.63 \%$ & $72.63 \%$ \\
9.40 & 40 & 6.78 & 6.33 & $67.73 \%$ & $66.44 \%$ \\
10.00 & 60 & 6.20 & 5.74 & $61.94 \%$ & $60.25 \%$ \\
10.20 & 80 & 6.06 & 5.30 & $60.54 \%$ & $55.63 \%$ \\
10.40 & 100 & 5.79 & 4.88 & $57.84 \%$ & $51-22 \%$ \\
11.00 & 120 & 5.40 & 4.35 & $53.95 \%$ & $45.66 \%$ \\
11.20 & 140 & 4.92 & 4.10 & $49.15 \%$ & $43.03 \%$ \\
11.40 & 160 & 4.19 & 4.06 & $41.86 \%$ & $42.61 \%$ \\
12.00 & 180 & 3.92 & 3.90 & $39.16 \%$ & $40.93 \%$ \\
12.20 & 200 & 3.70 & 3.71 & $36.36 \%$ & $38.89 \%$ \\
\hline
\end{tabular}

Tabel 5. Pengujian 4 penurunan kadar air tiap 20 menit (19 Agustus 2019).

\begin{tabular}{cccccc}
\hline Waktu & Menit & \multicolumn{3}{c}{ Massa Sampel Bahan } & \multicolumn{2}{c}{ Kadar Air Sampel bahan } \\
& \multicolumn{5}{c}{ Tray (gram } \\
\hline 9.00 & 0 & 6.62 & 5.99 & \multicolumn{2}{c}{ Tray } \\
9.20 & 20 & 6.62 & 5.99 & $72.63 \%$ & $72.63 \%$ \\
9.40 & 40 & 6.50 & 5.81 & $71.31 \%$ & $70.45 \%$ \\
10.00 & 60 & 6.05 & 5.65 & $66.38 \%$ & $68.51 \%$ \\
10.20 & 80 & 5.62 & 5.30 & $61.66 \%$ & $64.26 \%$ \\
10.40 & 100 & 5.17 & 5.06 & $56.72 \%$ & $61.35 \%$ \\
11.00 & 120 & 4.88 & 4.83 & $53.54 \%$ & $58.56 \%$ \\
11.20 & 140 & 4.47 & 4.53 & $49.04 \%$ & $54.93 \%$ \\
11.40 & 160 & 4.28 & 4.32 & $46.96 \%$ & $52.38 \%$ \\
12.00 & 180 & 4.06 & 4.10 & $44.54 \%$ & $49.73 \%$ \\
12.20 & 200 & 3.83 & 3.90 & $42.02 \%$ & $47.29 \%$ \\
12.40 & 220 & 3.61 & 3.72 & $39.61 \%$ & $45.11 \%$ \\
13.00 & 240 & 3.49 & 3.55 & $38.29 \%$ & $43.04 \%$ \\
13.20 & 260 & 3.28 & 3.37 & $35.99 \%$ & $40.85 \%$ \\
13.40 & 280 & 2.98 & 3.04 & $32.69 \%$ & $36.86 \%$ \\
\hline
\end{tabular}


Pada tabel 6 menjelaskan penurunan kadar air setiap 20 menit, dari hasil ini bisa mempercepat proses pengeringan pisang sesuai dengan kapasitas alat pengering pisang. Kombinasi dengan solar cell maupun panas matahari untuk lebih efisien dalam pengeringan pisang.

Dari pengujian yang telah dilakukan dari tiap pengujian dapat dilihat pada tabel 7 , menunjukkan waktu dalam pengeringan pisang salai. Pengeringan ini jika kondisi cuaca mendung maka pengiringan akan lebih lama. Namun keuntungannya pisang terjaga higienis dalam hal kebersihan, karena pisang tidak dihinggapi oleh lalat [11].

Dari hasil pengukuran waktu proses pengeringan didapatkan waktu rata-rata 212 menit atau sekitar 3 jam 32 menit. Proses pengeringan tercepat terjadi pada saat pengujian ke 2 yaitu 160 menit pada tray 1. Pengeringan terlama 280 menit pada pengujian 4 di tray 2 dan pengujian 5 pada tray 1 .

Dengan menggunakan asumsi waktu paling lama, maka alat yang dibuat sudah punya kemampuan yang lebih cepat untuk mengeringkan pisang dibanding metode tradisional yaitu dipanaskan secara langsung dengan sinar matahari paling cepat 3 hari.

Tabel 6. Pengujian 5 penurunan kadar air tiap 20 menit (20 Agustus 2019)

\begin{tabular}{|c|c|c|c|c|c|}
\hline \multirow{2}{*}{$\begin{array}{c}\text { Waktu } \\
9.00\end{array}$} & \multirow{2}{*}{$\begin{array}{c}\text { Menit } \\
0\end{array}$} & \multicolumn{2}{|c|}{$\begin{array}{c}\text { Massa Sampel Bahan } \\
\text { Tray (gram }\end{array}$} & \multicolumn{2}{|c|}{$\begin{array}{c}\text { Kadar Air Sampel bahan } \\
\text { Tray }\end{array}$} \\
\hline & & 7.25 & 5.19 & & \\
\hline 9.20 & 20 & 7.27 & 5.19 & $72.63 \%$ & $72.63 \%$ \\
\hline 9.40 & 40 & 7.10 & 5.01 & $70.93 \%$ & $70.11 \%$ \\
\hline 10.00 & 60 & 6.69 & 4.75 & $66.84 \%$ & $66.47 \%$ \\
\hline 10.20 & 80 & 6.19 & 4.44 & $61.84 \%$ & $62.13 \%$ \\
\hline 10.40 & 100 & 5.82 & 4.19 & $58.14 \%$ & $58.64 \%$ \\
\hline 11.00 & 120 & 5.53 & 3.97 & $55.25 \%$ & $55.56 \%$ \\
\hline 11.20 & 140 & 5.12 & 3.65 & $51.15 \%$ & $51.08 \%$ \\
\hline 11.40 & 160 & 4.90 & 3.43 & $48.95 \%$ & $48.00 \%$ \\
\hline 12.00 & 180 & 4.62 & 3.26 & $46.16 \%$ & $45.62 \%$ \\
\hline 12.20 & 200 & 4.47 & 3.01 & $44.66 \%$ & $42.12 \%$ \\
\hline 12.40 & 220 & 4.32 & 2.84 & $43.16 \%$ & $39.74 \%$ \\
\hline 13.00 & 240 & 4.18 & 2.73 & $41.76 \%$ & $38.20 \%$ \\
\hline 13.20 & 260 & 3.91 & 2.56 & $39.06 \%$ & $35.83 \%$ \\
\hline
\end{tabular}

Tabel 7 menjelaskan pengujian yang dilakukan beberapa kali untuk menentukan nilai rata-rata proses pengeringan.

Dari penurunan massa buah pisang yang dipanaskan, maka dapat diketahui penguapan massa air setiap 20 menitnya. Dari pengujian yang telah dilakukan dapat diketahui kemampuan alat untuk menguapkan air. Hal itu dapat kita lihat pada tabel 8. 
Tabel 7. Waktu pengeringan

\begin{tabular}{ccc}
\hline Pengujian & $\begin{array}{c}\text { tray 1 } \\
\text { (menit) }\end{array}$ & $\begin{array}{c}\text { tray 2 } \\
\text { (menit) }\end{array}$ \\
\hline pengujian 1 & 220 & 180 \\
pengujian 2 & 160 & 200 \\
pengujian 3 & 180 & 200 \\
pengujian 4 & 220 & 280 \\
pengujian 5 & 260 & 220 \\
\hline rata-rata & 208 & 216 \\
\hline rata-rata waktu & & \\
pengeringan & &
\end{tabular}

Tabel 8. Hasil pengujian penguapan

\begin{tabular}{|c|c|c|c|c|c|c|}
\hline Waktu & Menit & $\begin{array}{c}\text { Pengujian } 1 \\
\text { (gram) }\end{array}$ & $\begin{array}{c}\text { Pengujian } 2 \\
\text { (gram) }\end{array}$ & $\begin{array}{c}\text { Pengujian } 3 \\
\text { (gram) }\end{array}$ & $\begin{array}{c}\text { Pengujian } 4 \\
\text { (gram) }\end{array}$ & $\begin{array}{c}\text { Pengujian } \\
5 \text { (gram) }\end{array}$ \\
\hline 9.00 & 0 & & & & & \\
\hline 9.20 & 20 & 0 & 0 & 0 & 0 & 0 \\
\hline 9.40 & 40 & 1.05 & 0.22 & 0.54 & 0.15 & 0.18 \\
\hline 10.00 & 60 & 1.00 & 0.68 & 0.59 & 0.31 & 0.34 \\
\hline 10.20 & 80 & 0.60 & 0.32 & 0.29 & 0.39 & 0.41 \\
\hline 10.40 & 100 & 0.96 & 0.55 & 0.35 & 0.35 & 0.31 \\
\hline 11.00 & 120 & 0.51 & 0.53 & 0.46 & 0.26 & 0.26 \\
\hline 11.20 & 140 & 0.34 & 0.19 & 0.37 & 0.36 & 0.37 \\
\hline 11.40 & 160 & 0.37 & 0.29 & 0.39 & 0.20 & 0.22 \\
\hline 12.00 & 180 & 0.36 & 0.26 & 0.22 & 0.22 & 0.23 \\
\hline 12.20 & 200 & 0.42 & 0.45 & 0.20 & 0.22 & 0.20 \\
\hline 12.40 & 220 & 0.50 & & & 0.17 & 0.16 \\
\hline 13.00 & 240 & & & & 0.18 & 0.14 \\
\hline 13.20 & 260 & & & & 0.32 & 0.27 \\
\hline 13.40 & 280 & & & & 0.25 & \\
\hline
\end{tabular}

Jika rata-rata tiap 20 menit alat ini mampu menguapkan air $\left(\mathrm{m}_{\mathrm{ab}}\right)$ sebesar 0.38 gram, maka kemampuan penguapan air per jamnya.

$$
\begin{aligned}
\mathrm{M}_{\mathrm{ab}} & =\frac{\mathrm{mab}}{t} \\
& =\frac{0.38 \mathrm{gram}}{20 \text { menit }} \cdot\left(\frac{60 \mathrm{menit}}{1 \mathrm{jam}}\right)
\end{aligned}
$$


Bina Age Aratama, Awang Surya

Alat Pengering Sale Pisang Dengan Energi Surya

$$
\begin{aligned}
& =1.14 \mathrm{gram} / \mathrm{jam} \\
& =0.0114 \mathrm{~kg} / \mathrm{jam}
\end{aligned}
$$

Kemampuan alat pengering menyerap energi radiasi matahari kemudian diubah menjadi energi panas yang dipengaruhi oleh luas permukaan polikarbonat [12]. Alat pengering buah pisang ini menggunakan polikarbonat dengan luas permukaan (A) $1.66 \mathrm{~m}^{2}$. Dalam setiap pengujian alat pengering ini memperoleh intensitas cahaya matahari yang berbeda-beda tergantung kondisi cuaca di hari saat dilakukan pengujian [13]. Adapun besaran intensitas cahaya dapat dilihat pada tabel 9.

Tabel 9. Intensitas cahaya matahari

\begin{tabular}{ccccccc}
\hline Waktu & Menit & $\begin{array}{c}\text { Pengujian 1 } \\
\text { (gram) }\end{array}$ & $\begin{array}{c}\text { Pengujian 2 } \\
\text { (gram) }\end{array}$ & $\begin{array}{c}\text { Pengujian 3 } \\
\text { (gram) }\end{array}$ & $\begin{array}{c}\text { Pengujian 4 } \\
\text { (gram) }\end{array}$ & $\begin{array}{c}\text { Pengujian } \\
5 \text { (gram) }\end{array}$ \\
\hline 9.00 & 0 & & & & & \\
9.20 & 20 & 72000 & 17700 & 17900 & 6880 & 6530 \\
9.40 & 40 & 85100 & 40000 & 39000 & 7740 & 7500 \\
10.00 & 60 & 104000 & 119000 & 24500 & 8600 & 8350 \\
10.20 & 80 & 92100 & 124500 & 39100 & 10100 & 10700 \\
10.40 & 100 & 87500 & 178300 & 29200 & 11910 & 11300 \\
11.00 & 120 & 51000 & 292100 & 16000 & 12700 & 14500 \\
11.20 & 140 & 77100 & 215000 & 19100 & 13330 & 11500 \\
11.40 & 160 & 18200 & 292500 & 14300 & 12400 & 13000 \\
12.00 & 180 & 22000 & 114300 & 10100 & 87000 & 85500 \\
12.20 & 200 & 17000 & 110000 & 10700 & 70400 & 69300 \\
12.40 & 220 & 17100 & & & 13500 & 12860 \\
13.00 & 240 & & & & 25100 & 22300 \\
13.20 & 260 & & & & 15100 & 14500 \\
13.40 & 280 & & 53400 & 21990 & 24869 & 22142 \\
\hline Rata-Rata & 58464 & 150340 & & & \\
\hline
\end{tabular}

Dari pengujian di atas di rata-rata alat pengering memperoleh sebesar 55561 LUX atau 83.11888 $\mathrm{W} / \mathrm{m}^{2}\left(1 \mathrm{LUX}=0,001496 \mathrm{~W} / \mathrm{m}^{2}\right)$. Besarnya laju energi yang diserap oleh polikarbonat dan dari data rata-rata ke 5 pengujian dapat dihitung dengan persamaan.

$$
\begin{aligned}
Q_{\text {in }} & =\mathrm{A} \cdot \mathrm{It} \\
& =1.66 \mathrm{~m}^{2} \cdot 83.11888 \mathrm{~W} / \mathrm{m}^{2} \\
& =137.97734 \mathrm{~W} \\
& =0.138 \mathrm{KW}
\end{aligned}
$$


Efisiensi termal pengeringan merupakan perbandingan energi pengeringan yang digunakan dengan energi total yang diterima alat [14]. Dari penelitian yang telah dilakukan didapat efisiensi termalnya dari tiap pengujian dijelaskan pada tabel 10 .

Tabel 10. Efisiensi termal ( $\eta$ th).

\begin{tabular}{lc}
\hline & $\begin{array}{c}\text { Efisiensi Termal } \\
(\eta \text { th })\end{array}$ \\
\hline pengujian 1 & $16.99 \%$ \\
pengujian 2 & $18.09 \%$ \\
pengujian 3 & $18.32 \%$ \\
pengujian 4 & $12.60 \%$ \\
pengujian 5 & $12.52 \%$ \\
\hline
\end{tabular}

Dari tabel 10 maka alat pengering buah pisang memiliki efisiensi termal ( $\eta$ th) rata-rata sebesar $15.70 \%$.

\section{SIMPULAN}

Alat yang dibuat telah berfungsi sebagaimana mestinya. Alat ini punya kemampuan mengeringkan buah pisang sampai kadar air menjadi di bawah $40 \%$. Waktu yang dibutuhkan rata-rata 212 menit atau 3 jam 32 menit. Kapasitas penguapan kadar air dari alat yang dibuat adalah sebesar $0.0114 \mathrm{~kg} / \mathrm{jam}$. Efisiensi termal dari alat yang dibuat adalah sebesar $15.70 \%$. Selanjutnya, sebagai perbaikan perlu dilakukan perbaikan untuk penelitian selanjutnya mencoba menggunakan penutup alat selain polycarbonate. Bahan-bahan seperti kaca es sangat mungkin punya kemampuan meningkatkan alat.

\section{DAFTAR PUSTAKA}

[1] I. Adhayanti, T. Abdullah, and R. Romantika, "UJI KANDUNGAN TOTAL POLIFENOL DAN FLAVONOID EKSTRAK ETIL ASETAT KULIT PISANG RAJA (Musa paradisiaca var. sapientum)," Media Farm., 2018.

[2] Y. Sugiarti, "PERANCANGAN SISTEM INFORMASI AGRIBISNIS E-COMMERCE BUAH PISANG,” Agribus. J., 2014.

[3] T. K. Putri et al., "Pemanfaatan jenis-jenis pisang (banana dan plantain) lokal Jawa Barat berbasis produk sale dan tepung," Kultivasi, 2015.

[4] D. Hasanah, Uswatun Mayshuri, "Analisis Nilai Tambah Agroindustri Sale Pisang di Kabupaten Kebumen The Value Added Analysis of Sale Pisang Agroindustry in Kebumen Regency," Ilmu Pertan., 2015.

[5] P. Studi, A. Fakultas, P. Universitas, and S. Maret, "PISANG DI KABUPATEN GROBOGAN Denok Setia Pratiwi, Sugiharti Mulya Handayani, Emi Widiyanti PENDAHULUAN 
Alat Pengering Sale Pisang Dengan Energi Surya

Indonesia mempunyai berperanan penting dalam paradigma keunggulan komparatif ( comparative baru karena dapat meningkatkan advantage ) sebagai negara a," no. 36.

[6] F. Nurainy, S. Hidayati, D. Koesoemawardani, and E. Suroso, "Penyuluhan dan pelatihan pengolahan sale pisang kelompok usaha bersama aisyah di desa sukajawa kecamatan bumi ratu nuban kabupaten lampung tengah,” J. Pengabdi. Kpd. Masy., 2017.

[7] B. H. Purwoto, "EFISIENSI PENGGUNAAN PANEL SURYA SEBAGAI SUMBER ENERGI ALTERNATIF," Emit. J. Tek. Elektro, 2018.

[8] lili sari A. Purba and K. Harahap, "KONTRIBUSI KUAT LENTUR POLIKARBONAT PADA PELAT BETON BERPORI," J. Chem. Inf. Model., 2019.

[9] M. A. Billiris, T. J. Siebenmorgen, and G. L. Baltz, "Energy use and efficiency of rice-drying systems I. ON-Farm cross-Flow dryer measurements," Appl. Eng. Agric., vol. 30, no. 2, pp. 205-215, 2014.

[10] “Kupdf.Net_Sni-01-2891-1992-Cara-Uji-Makanan-Dan-Minumanpdf.Pdf.” .

[11] M. Wakjira, "Solar drying of fruits and windows of opportunities in Ethiopia," African J. Food Sci., vol. 4, no. 13, pp. 790-802, 2010.

[12] A. Tiwari, "A Review on Solar Drying of Agricultural Produce," J. Food Process. Technol., vol. 7, no. 9, 2016.

[13] F. G. Sayyad et al., "Design and Development of Solar Cooker cum Dryer," Curr. World Environ., vol. 10, no. 3, pp. 985-993, 2015.

[14] A. Mujumdar, C. Strumiłło, P. Jones, and R. Żyłła, "Energy Aspects in Drying," Handb. Ind. Drying, Fourth Ed., no. September, pp. 1077-1100, 2014. 